\title{
Trends and Challenges of Manufacturing Management in Industry 4.0
}

\author{
Bogdan ARSENE \\ Transilvania University of Brasov, Romania, arsene.bogdan@unitbv.ro \\ Gavrilă CALEFARIU \\ Transilvania University of Brasov, Romania, gcalefariu@unitbv.ro
}

\begin{abstract}
Today's globalization is creating and is bringing new opportunities for sustainable development. New emergent markets are rising, thus more environment friendly new innovative solutions for meet current demand are released. The global economy is facing today with many challenges and for manufacturing systems in order to be competitive on the global market it is mandatory to innovate permanently. Industry 4.0 (I4.0) with its main component smart factory i.e. factory of the future may be seen like an innovation in manufacturing field. Factory of the future (FoF) will be driven by intelligent manufacturing systems, characterized by smart machines, smart equipment, smart operators and smart products with the purpose to achieve mass customization, industrial growth and added value. The newest information and communication technologies play a key role in development of the smart factory and together with the physical devices lead to creation of so called Cyber-Physical System (CPS) which is the core of FoF. This paper contains a systematic study of the researches undertaken in the field of I4.0 and reveal the trends and the challenges of manufacturing management both those presented by literature and those resulting from direct researches of the authors, in four categories.
\end{abstract}

\section{Keywords}

trends, challenges, manufacturing management, Industry 4.0, CPS

\section{Introduction}

Industry 4.0 (I4.0) has become nowadays one of the most approached subject in manufacturing research field. This initiative is synonymous with digitalization of the production systems. Digitization is seen by many institutions, researchers and firms as the fourth industrial revolution [ 1 ... 6]. A summary of the industrial revolutions is presented below:

$>1^{\text {st }}$ industrial revolution (end of $18^{\text {th }}$ century) was governed by mechanization and steam power;

$>$ the $2^{\text {nd }}$ one (end of $19^{\text {th }}$ century) was dominated by mass production, steel industry, combustion engine and electricity;

$>$ the $3^{\text {rd }}$ (second half of the 20th century) marked the rise of electronics and computers and production automation [7].

The $4^{\text {th }}$ industrial revolution is represented by the new information and communication technologies (ICT) e.g. Cloud Computing, Big Data, Cloud Manufacturing, real-time localization, Internet of Things (IoT), Internet of Services (IoS), Internet of Data (IoD), Internet of People (IoP) and Internet of Everything (IoE) $[3,4,8 \ldots 11]$ which comes like an evolution for the existing approaches e.g. ComputerIntegrated Manufacturing (CIM) and Lean \& Agile Manufacturing. Figure 1 presents a background of the industrial revolutions.

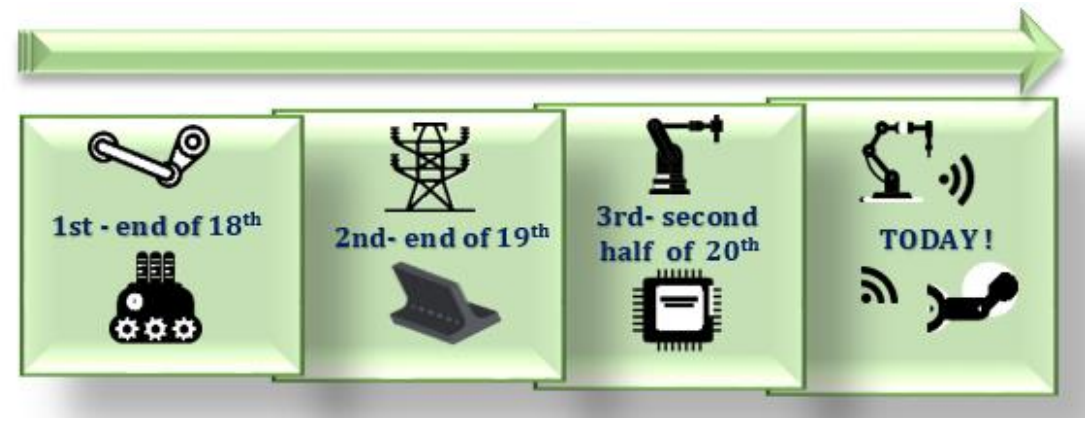

Fig. 1. Background of industrial revolutions 
Even if I4.0 is considered the $4^{\text {th }}$ industrial revolution by most, there are voices which strengthens the idea that this concept is an industrial evolution rather than an industrial revolution [12]. Anyway, this initiative may be seen as an innovation in industrial engineering and production systems, especially in manufacturing. This concept turns the nowadays manufacturing in an automated and digitized manufacturing $[4,13]$ able to made smart products $[1,3,4,8,10]$ and gentelligent components [13]. I4.0 tends to significantly change of traditional processes involved in manufacturing systems. According to $[1,2,4,5,6,8,10]$ the implementation of "Industry 4.0 " yields a lot of benefits for manufacturing system e.g. novel business and pricing models, an increase of flexibility, productivity and competitiveness, cost savings, processes optimization mainly machining and maintenance, and improving customer relations, but also is rising lots of concerns regarding employment, employers' skills, investment needs, network environment and data security $[2,4,14,15,16]$.

The main element of I4.0 is the concept of the smart factory $[1,17,18]$. The traditional factory become smart factory, more flexible and more autonomous, sustainable, with smart equipment and machines able to collect, storage, interpret and exchange mass data with another entities, with smart operators and smart products $[1,4,8,18]$ having as main aim business performance improvement.

\section{Key Technologies Involved in Industry 4.0}

I4.0 is closely linked by the new ITC technologies. The internet of things (IoT) represents a largescale network of interconnected devices, machines, equipment, sensors, and actuators, robots able to communicate with each other $[6,10,11,19,20,21]$. In production systems, this network is called Industrial Internet of Things (IIoT) and is part of IoT [21, 22]. The communication between "things" i.e. data exchange in production systems is achieved by so-called CPS $[1,3,6,9,18,23]$ designed to tightly merge the physical world and the virtual world [9], using wireless networks, radio-frequency identification (RFID), cloud technologies [10] and other emerging IT's. The CPS embed cameras, minicomputers, mechatronic components (e.g. actuators and sensors), microchips and autonomous systems $[3,10,18]$ which collect information, measure characteristics of products and processes [5], communicate and safeguard men (socio-CPS) [9, 24]. In manufacturing field, this system is called CyberPhysical Production System (CPPS) [1, 6, 10, 25]. All these technologies are moving forward to a worldwide network with interconnected entities e.g. equipment, machine-tools and devices [11], with available data anytime and anywhere [6] and change the relationships throughout the supply chain in terms of trust and satisfaction [10].

RFID is a wireless rapidly growing technology, which is increasingly used in industry and beyond due to the considerable benefits that offers in different fields as logistic, manufacturing or supply-chain management $[26,27,28]$. It is used for example in supply chains for containers, pallets or parcels tracking, to increase of delivery performance and to reduce, in the recycling field to improve the waste management efficiency, access control and payments [26, 27].

RFID system is an automatic identification system, without contact, which can identify entities and consist in three fundamental elements as reader, tag and middleware software [26, 27, 29]. The RFID tag, which contains integrated circuits, antenna and chips, is attached to a product or incorporated in products, allow data storage and has an electronic product code (EPC), unique in the world [26, 27, 29].

The role of reader is to read data stored and to write new data in tag [29] and communicates with the tag within radio frequencies [27]. The reader comes in various forms, and the configuration and complexity depends on the functions to accomplish, but the main functions is to ensure the communication with the tag $[26,27]$. The antenna has the role to transmit the signal (radio frequencies) between tag and reader [29]. When the tag is found in the magnetic fields of the reader, it receives signal and can transfer data stored [29]. The role of middleware software is to convert the data stored in tag into relevant information, to solve different errors of reader and to ensure that bad or useless reads are removed $[26,27]$. Depending of the power source, there are three types of tags: active, passive and semipassive $[26,27]$. The power source of a tag is a key feature since it determines the read range, the cost and the lifetime of the system [27]. The active tags have, in general, an internal battery and have the ability to start their own communication with readers [27], while the passive tags don't have own power source and absorb energy provided by the reader [26, 27]. Even if the passive tags have a shorter read 
range them active tags and their reading capacity depends on the material of the items in which they are embedded, the passive tags are the most often used tags due to the small size, cheap manufacturing, easy integration into products and don't require maintenance [26, 27]. The semi-passive tags have their own power source as active tags but communicate in the same manner as passive tags [26,27]. The read range of the active and semi-passive tags can be up to 100 meters [27], since the passive tags read range varies from 0.1 meters if is using low frequency $(125 \mathrm{kHz})$ up to 10 meters if is using microwave (2.4 $\mathrm{GHz})[26,27,28]$. The future of the tags seems to be focused in eliminating the chip and manufacturing from biodegradable materials $[26,28]$, but also the concerns regarding systems security is considered [27].

The Big data concept, which refer to a huge volume of complex and heterogeneous data, bring a new horizon of opportunities [22] and may be a valuable resource to gain competitive advantage. This concept has expanded the technological capabilities of storing, managing, processing, interpreting and viewing a large amount of data and is characterized by four dimensions (4V): volume (amount of data), variety (data are extracted from a variety of sources), velocity (the speed of new data generation, acquisition and analysis) and value [22, 30,31]. The main activities related to this concept are data mining, classification and storage [10,32]. By acquiring and analyzing large amount of data the manufacturers or sellers will be able to improve the products features and the processes involved, to predict the customers' behavior and to respond faster and better to their requests [10, 22, 30, 31].

Cloud computing (CC) is an IT concept which consists in providing of computing services e.g. software, platforms or storage [22,33]. The cloud computing services models are: infrastructure as a service (IaaS), platform as a service (PaaS) and software as a service (SaaS) [16, 22]. IaaS provides companies IT resources as networking, servers and storage on a pay-per-use system [34] and has the strongest link with the computing infrastructure [35]. Likewise, the clients have the possibility for accessing and configuring the resources offered by cloud infrastructure as needed [36]. Such a system has some advantages as follows: isn't necessary investment in own hardware, the infrastructure scales on demand (adjusts the amount of resources allocated automatically, as needed) to support dynamic workloads and offers innovative and flexible on-demand services [34]. PaaS is primarily aimed to developers and provides a cloud-based environment with everything needed to fully support the development and delivery of applications, without being necessary to acquire and manage, hosting, software and hardware [34, 35]. The advantages of this model are linked to the faster development of applications and to the shorter time for release new web applications in the cloud [34]. Through the SaaS model, the client can use software provided by a provider on a cloud infrastructure. The cloudbased applications are hosted by a provider and run on distant computers that connect to user's computer via the internet $[34,35,36]$. In manufacturing, such a service can be represented by the applications developed by the cutting tools or machine-tools manufacturers for machining optimization. The advantages of this model are linked to the quick and easy use of innovative applications, data availability on any connected computer and minimal risk of data lose since the data is stored in cloud [34].

Cloud manufacturing (CMfg) is "a computing and service-oriented manufacturing model" [33] or "a networked manufacturing model" [21] and at the same time an emerging paradigm for the modern manufacturing industry $[37,38]$ with the purpose to turn the free manufacturing resources and capabilities into safe, cheap, reliable and on-demand services [33,39]. CMfg is part of CC and integrates, in addition to cloud computing, other models e.g. design as a service (DaaS), simulation as a service (SIMaaS), management as a service (MaaS) and maintenance as a service (MaaaS) [33, 37]. Through this emerging technology the users can require various services such as design, manufacturing, testing, management or any other stage from the life cycle of a part for example, in a pay-as-you-go manner [21, $33,37]$.

The cloud manufacturing architecture is composed from three layers corresponding to cloud server, local server and physical resources [38].

The main challenges of ICT's, presented in literature, in I4.0 are listed in Table 1.

An overview of the key technologies involved in I4.0 is presented in figure 2 . 
RECENT, Vol. 19, no. 2(55), November, 2018

Table 1. Challenges for ICT in Industry 4.0

\begin{tabular}{lc}
\hline \multicolumn{1}{c}{ Challenge } & References \\
\hline IT infrastructure & {$[1,19,40]$} \\
\hline Data collection, storage and management & {$[11,16,22,30]$} \\
\hline Data security & {$[1,3,4,5,16,19,22]$} \\
\hline Data conversion in same format & {$[19,22]$} \\
\hline Bad or useless data acquisition & {$[30]$} \\
\hline High speed data transfer/ 5G & {$[1,40,41]$} \\
\hline Developing new encryption methods & {$[1,4,42]$} \\
\hline
\end{tabular}

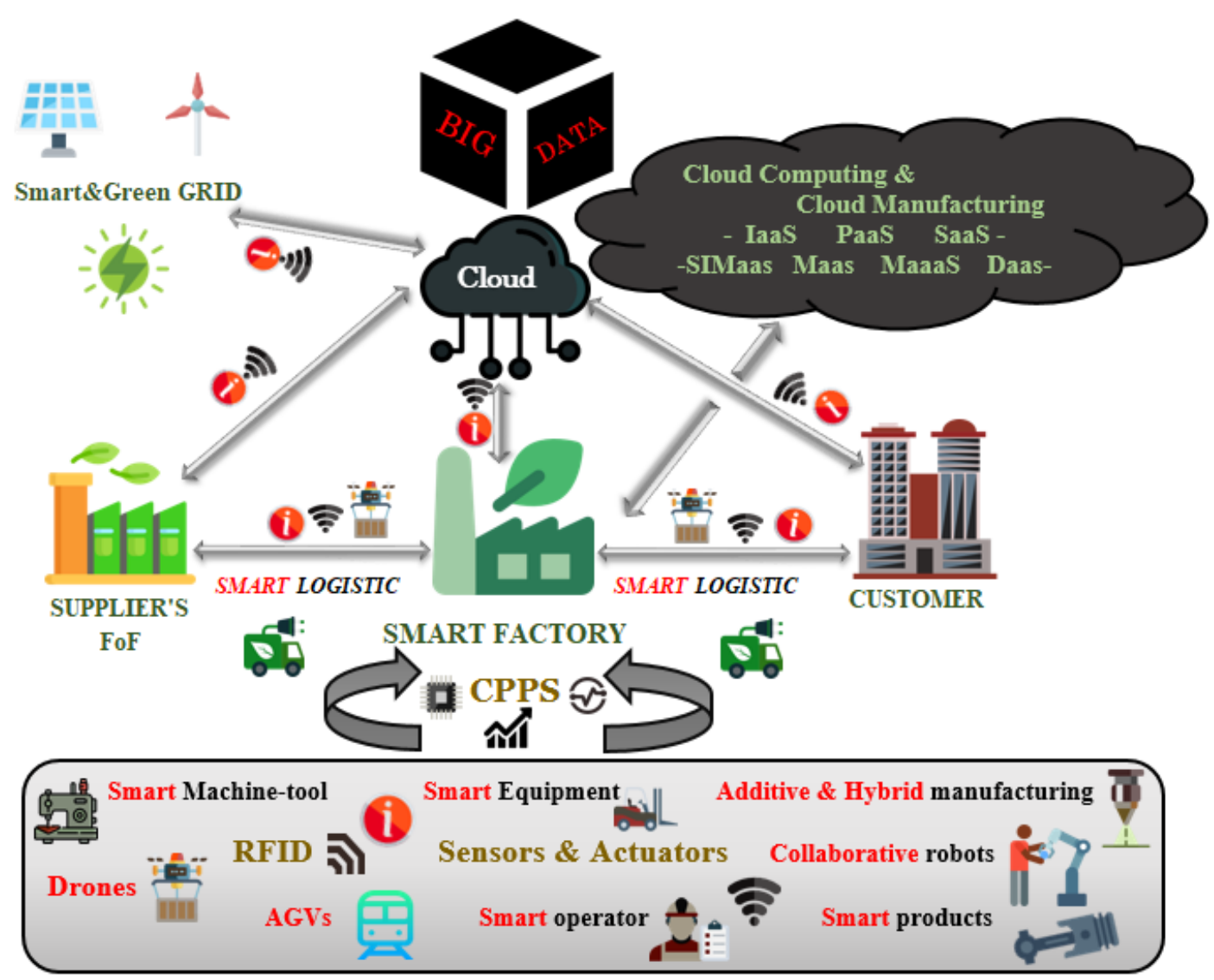

Fig. 2. Overview of the key technologies involved in I4.0

\section{Trends and Challenges of Manufacturing Management in Industry 4.0}

The trends and challenges are shared and discussed in four main categories closely linked by manufacturing management:

$>$ Human resource (safety \&s kills);

$>$ Quality: maintenance and machine tool;

$>$ Logistics \& planning;

$>$ Costs and the economic impact.

\subsection{Human resource in Industry 4.0 (employees' safety $\&$ skills)}

The competitiveness and success of a plant in the market, first, is provided by human resource [43], thus a safety and ergonomic environment shall to be available. Safety is found in many companies' sustainability initiatives and is seen as a competitive advantage [44], thus it can be strengthened the idea that the development of new business models in I4.0 era starts with employees' safety and well-being. The trends linked to human resource (HR) in I4.0, presented in literature, are listed in Table 2. 
RECENT, Vol. 19, no. 2(55), November, 2018

Table 2. Trends linked to HR in I4.0

\begin{tabular}{|c|c|c|}
\hline Trend & References & Discussion \\
\hline $\begin{array}{l}\text { Augmented } \\
\text { Reality }\end{array}$ & {$[8,14,45,46]$} & $\begin{array}{l}\text { - may be helpful in use of complex equipment or may be } \\
\text { used for to easily solve some difficult task on working } \\
\text { station; a cheap and fast solution for training }\end{array}$ \\
\hline $\begin{array}{c}\text { Collaborative } \\
\text { robots }\end{array}$ & {$[47,48]$} & $\begin{array}{l}\text { - may take from operators the hardest and the most } \\
\text { dangerous tasks }\end{array}$ \\
\hline $\begin{array}{c}\text { Mobile } \\
\text { applications }\end{array}$ & [49] & $\begin{array}{l}\text { - ensure evaluation of risks at workplaces and creation } \\
\text { of more ergonomic workplaces }\end{array}$ \\
\hline $\begin{array}{l}\text { Human machine } \\
\text { interfaces }\end{array}$ & $\begin{array}{l}{[18,25,46,} \\
50,51]\end{array}$ & $\begin{array}{l}\text { - ensure and allow the communication between } \\
\text { machine and users and provide access to data and } \\
\text { information sharing; the link between cyber and } \\
\text { physical word }\end{array}$ \\
\hline $\begin{array}{l}\text { Smart operator } \\
\text { and smart } \\
\text { technician } \\
\end{array}$ & $\begin{array}{c}{[14,15,19} \\
52,53]\end{array}$ & $\begin{array}{l}\text { - new ICT require novel skills and qualifications for } \\
\text { employees in many fields e.g. operations management, } \\
\text { data science and supply chain management }\end{array}$ \\
\hline $\begin{array}{c}\text { Learning } \\
\text { factories and } \\
\text { modules for I4.0 }\end{array}$ & {$[15,25,54]$} & $\begin{array}{l}\text { - ensure high performance in developing new abilities } \\
\text { and knowledge gaining regarding modern technologies }\end{array}$ \\
\hline
\end{tabular}

Regarding safety, lots of plants are using traditional handling equipment e.g. gantry cranes, forklifts, lift pallet and a lot concerns regarding safety for operators that serve them are rising. In FoF, these equipment will become smart, will be able to recognize if the operator wears safety equipment and will communicate with the operator via Human-Equipment Interfaces (HEI). Will can be use only by the licensed operators and will provide real-time data (in second or milli-seconds) about operator ID, use time, load, route, energy consumption or battery status and faults to local server. Data acquired will provide reports to safety responsible about equipment condition, damages and proper use in order to establish preventive actions (e.g. maintenance schedule, teaching) for safety and security. A possible model for these smart equipment is presented in Figure 3.

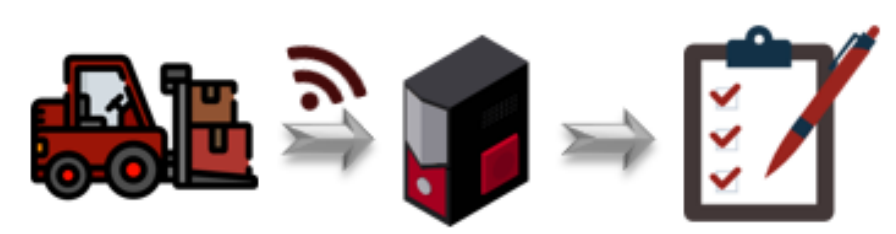

Fig. 3. Real-time data transfer from equipment to local server

The mobile applications are increasingly used in safe and ergonomic workstations. Such a smart solution is described in [49] and is used for fast evaluation of risk at workplaces.

In the future smart factories, the augmented reality (AR) and collaborative robots (Cobots) also will play a significant role in safety. The AR technology supported by smart mobile tools e.g. glasses and tablets $[14,45,46]$ and smart gloves may be helpful for operators mainly in use of complex equipment, and the cobots, which cooperate with the operators (human-robot collaboration) [47, 48], may take from these the hardest and the most dangerous tasks.

Regarding skills of the employees, I4.0 brings new challenges for companies. The employees will meet more sophisticated process and will have more responsibilities at workplaces, thus novel technical skill and job profiles are required $[14,15]$. Among many requirements, the employees shall to have for example knowledge of communication and security standards and methods [53], knowledge of use smart devices [14, 25] and knowledge to carry out some of the process failures or errors without maintenance crew [15].

The emerging technologies have high impact in education and training [25,53], thus companies shall focus on new qualification strategies for staff and shall develop new strategies to attract young people 
[43] since skills and qualifications of the workforce will lead to meet the challenges in I4.0. The main challenges linked to HR in I4.0, presented in literature and identified by the authors, are listed in Table 3.

Table 3. Challenges linked to HR in I4.0

\begin{tabular}{lc}
\hline \multicolumn{1}{c}{ Challenge } & References \\
\hline $\begin{array}{l}\text { Computation of safety distance between } \\
\text { robots and workers }\end{array}$ & {$[48]$} \\
\hline Retrofitting the traditional equipment & Authors hypothesis \\
\hline $\begin{array}{l}\text { Training of the operators and technicians } \\
\text { regarding modern technologies }\end{array}$ & {$[14,15,25,53,55]$} \\
\hline New skilled and young workforce & {$[5,15,43,55]$} \\
\hline
\end{tabular}

\subsection{Quality: maintenance and machine tool in Industry 4.0}

The processes involved in manufacturing smart factory become more complex, automated, dynamic [56] and more sophisticated and this fact leads to new challenges for quality and quality management. To face these challenges, new techniques e.g. data mining must be implemented for quality improvement [57]. The trends linked to quality in I4.0, presented in literature and identified by the authors, are listed in Table 4.

Table 4. Trends linked to quality in I4.0

\begin{tabular}{ccl}
\hline Trend & References & \multicolumn{1}{c}{ Discussion } \\
\hline $\begin{array}{c}\text { Smart machine tool } \\
\text { or machine tool } 4.0\end{array}$ & {$[3,42,51,58]$} & $\begin{array}{l}\text { ・ machine tool will be equipped with lots of } \\
\text { sensor measuring different features, will have } \\
\text { an intelligent system for cutting monitoring and } \\
\text { will hold an intelligent predictive maintenance } \\
\text { based on robust analysis algorithms }\end{array}$ \\
\hline Machine learning & {$[4,6,20,51$,} & $\begin{array}{l}\text { - the machines will have capabilities for self- } \\
\text { optimization and autonomous decision-making } \\
\text { to improve process }\end{array}$ \\
\hline $\begin{array}{c}\text { Machine to machine } \\
\text { communication }\end{array}$ & {$[18,40,51]$} & $\begin{array}{l}\text { - allow communication between machines; } \\
\text { cooperative manufacturing by real-time data } \\
\text { transfer }\end{array}$ \\
\hline $\begin{array}{c}\text { Remote maintenance } \\
\text { using Augmented } \\
\text { Reality }\end{array}$ & {$[45,46,60]$} & $\begin{array}{l}\text { - it helps to reduce reaction time at failures and } \\
\text { to reduce maintenance tasks errors }\end{array}$ \\
\hline $\begin{array}{c}\text { Wireless measuring } \\
\text { tools }\end{array}$ & Authors & $\begin{array}{l}\text { - ensure and allow the communication between } \\
\text { equipment and users and provide access to } \\
\text { data; the link between cyber and physical word }\end{array}$ \\
\hline
\end{tabular}

The machine tool plays a key role in product quality. In I4.0, the nowadays machine tool will become "Machine Tool 4.0" (MT 4.0), more autonomous and smarter [51], e.g. by using RFID labels and readers the machine-tool will be able to detect and recognize each part from the flow (i.e. machine-part communication). The MT4.0 will be equipped with sensors that measure and collect data about vibrations, forces, temperatures in cutting zone [38,51], remaining useful-life of components, and real volume and pressure of coolant, to reach the maximum overall equipment effectiveness (OEE), to avoid burns and cracks on the products surfaces and tools cracking or chipping. MT 4.0 equipped with sensing technology for different parameters contributes significantly to product quality improvement $[38,51]$. It is widely known that the vibrations of the main machine-tools parts e.g. spindle and screw ball represent a huge problem especially on those that perform final machining operation i.e. finishing hard turning and grinding, hence a complex system based on robust analysis algorithms [42] is required to allow identification of the correlation between cutting parameters, vibrations occurred, spare parts 
status and surface quality in order to optimize the process according to existing conditions and to prevent failures. MT 4.0 will hold an Intelligent Predictive Maintenance (IPM) system [32, 58] which will ensure prognostics and health management [51] and which will allow to detect and prevent possible failures caused for example by spare parts with low useful-life (Maintenance 4.0). If preventive maintenance it's scheduled very often lead to high costs and if it's performed few times can lead to failures, stops and scraps which involve high repair cost failure cost [59] and loss of production capacity, thus robust analysis algorithms and data mining tools \& techniques may provide information to IPM system in order to schedule the equipment maintenance right on time. All functions will be integrated in Cyber-Physical Machine Tools (CPMT) [51].

In maintenance, another bright trend is remote maintenance using an application, a tablet and Augmented Reality (AR). This kind of system is described in [60] and may be a cheap and fast solution in Maintenance 4.0.

Another benefit which 14.0 can bring in Quality 4.0 is an increase in communication and business relations among supplier, manufacturer and customer. In I4.0 the plants will exchange real-time data about measured features with the support of wireless measuring tool and will be able to respond very fast in case of any deviation. Data about measurements is send fast to quality responsible and it can quickly assess the situation and decide if it's necessary to quickly inform the customer. It will be a fast communication between supplier and customer to avoid losses. The system will work in all the supply chain i.e. from raw material supplier to manufacturer, from manufacturer to manufacturer customer's and so on and will bring an increase of raw material and products quality. A possible model for this system is presented in Figure 4.

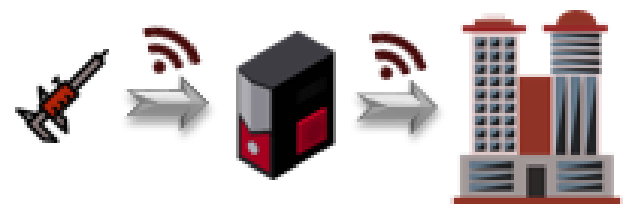

Fig. 4. Real time quality data transfer

The challenges linked to quality in I4.0, presented in literature, are listed in Table 5.

Table 5. Challenges linked to quality in I4.0

\begin{tabular}{lc}
\hline \multicolumn{1}{c}{ Challenge } & References \\
\hline $\begin{array}{l}\text { Implementation of sensing technologies and } \\
\text { machine tool retrofitting/upgrading }\end{array}$ & {$[51,58]$} \\
\hline $\begin{array}{l}\text { Development of intelligent predictive } \\
\text { maintenance }\end{array}$ & {$[51,58]$} \\
\hline Development of robust analysis algorithms & {$[58]$} \\
\hline Machines control & {$[22,55]$} \\
\hline Improving tracking algorithms for AR & {$[60]$} \\
\hline
\end{tabular}

\subsection{Logistics \& planning in Industry 4.0}

Logistic 4.0 (L4.0) is focusing on high transparency and visibility, small batch size or batch size one, use of self-driving \& green trucks and use of drones for delivering lightweight goods [3, 5, 6, 61]. The traditional supply chain will become digital supply chain and will embed many elements e.g. smart warehousing, prescriptive supply chain analytics, autonomous and B2C (business-to-client) logistics and digital supply chain enablers [62]. It will be a significant impact of these trends in costs and pollution reduction, in customer relations and in gaining competitive advantage. The trends linked to logistics and planning in I4.0, presented in literature, are listed in Table 6.

The implementation of the newest ICT in logistic field will bring a growth of traceability and transparency by using real-time localization of products in the entire supply chain $[65,66,67]$, will aid to avoid the "bullwhip effect" $[29,68]$, will help to decrease the incorrect deliveries (especially in 
inbound logistic) and documentation efforts [73], will afford companies to react faster to unexpected and risky situations throughout the supply chain [29,61], will help to reduce work-in-progress (WiP) and will abolish loss of products. Smart systems as intelligent routing systems and end-to-end route optimization systems will allow high efficiency of inbound and outbound logistic [66]. All these benefits lead to an increase of delivery performance.

Table 6. Trends linked to logistics and planning in I4.0

\begin{tabular}{|c|c|c|}
\hline Trend & References & Discussion \\
\hline Batch size one & {$[1,3,5]$} & $\begin{array}{l}\text { - allow customized product at reasonable } \\
\text { price, making profit }\end{array}$ \\
\hline $\begin{array}{c}\text { Self-driving \& green } \\
\text { trucks }\end{array}$ & {$[5,47]$} & - eco-friendly and cheap logistic \\
\hline $\begin{array}{l}\text { Drones for delivering } \\
\text { lightweight goods }\end{array}$ & {$[6,61]$} & $\begin{array}{l}\text { - effortless way, fast and eco delivery for } \\
\text { lightweight goods }\end{array}$ \\
\hline AGVs' & {$[1,3,63,64]$} & $\begin{array}{l}\text { - will be "interconnected via wireless } \\
\text { communication [94]" and will be used in } \\
\text { internal logistic }\end{array}$ \\
\hline $\begin{array}{l}\text { Radio-frequency } \\
\text { identification (RFID) of } \\
\text { products or carry unit }\end{array}$ & $\begin{array}{c}{[26 \ldots 29} \\
64 \ldots 67,69]\end{array}$ & $\begin{array}{l}\text { - RFID bring a growth of traceability, } \\
\text { transparency and visibility in the entire } \\
\text { supply chain }\end{array}$ \\
\hline $\begin{array}{l}\text { Intelligent routing } \\
\text { systems and end-to- } \\
\text { end route optimization }\end{array}$ & {$[66]$} & $\begin{array}{l}\text { - high efficiency of external logistic by } \\
\text { continuous optimization depending on traffic } \\
\text { conditions }\end{array}$ \\
\hline $\operatorname{PI}(\pi)$-container & {$[69,70]$} & $\begin{array}{l}\text { - a new paradigm that may be the smart load } \\
\text { unit }\end{array}$ \\
\hline $\begin{array}{l}\text { Future demand } \\
\text { predicts }\end{array}$ & {$[29,54,66]$} & $\begin{array}{l}\text { - customer future demand can be predicted } \\
\text { using big data analyse and data mining } \\
\text { techniques }\end{array}$ \\
\hline Agile ERP & {$[71,72]$} & - best production planning in time and space \\
\hline
\end{tabular}

Inbound logistic (IL) and outbound logistic (OL) will take a step forward i.e. smart equipment and RFID tracking will push the traditional IL and OL to smart IL and smart OL. The material and products flow in smart factories will be high transparency i.e. loss of components and product may be fully avoided.

Based on big data analyse the production planning will be improved and future demand may be predicted with certain accuracy $[22,29,66]$. Agile ERP will be able to achieve the best planning in time and space, very fast, in accordance with future demand, using linear programming algorithms [71], predictive analysis aided by data mining, and decision support systems [72].

Last but not least, a new trend in logistic field is so called $\pi$-container in the Physical Internet (PI) $[69,70]$. PI is a new paradigm which tends to radically change the logistic systems in terms of moving, handling, storage and supplied [69]. The $\pi$-container may be the smart load unit [69] in L4.0.

The challenges linked to logistics in I4.0, presented in literature and identified by the authors, are listed in Table 7.

Table7. Challenges linked to logistics in I4.0

\begin{tabular}{lc}
\hline \multicolumn{1}{c}{ Challenge } & References \\
\hline $\begin{array}{l}\text { Transition to eco-friendly/green delivery } \\
\text { transport type }\end{array}$ & {$[5,61]$} \\
\hline Adoption of modern technologies & {$[61,65,66]$} \\
\hline $\begin{array}{l}\text { Integration of all the supply chain } \\
\text { stakeholders in L4.0 }\end{array}$ & Authors hypothesis \\
\hline Design of PI $(\pi)$-container & {$[69,70]$} \\
\hline
\end{tabular}




\subsection{Costs and the economic impact in Industry 4.0}

All the trends launched by digitalization in HR, quality, logistic and not only, entail a new costs map in manufacturing. While it is expected an increase of cost for ICT, human resource development and equipment retrofitting as well it is foreseen a massive cost reduction specially process costs e.g. machining (tools, energy, labor), assembly, packing and maintenance. The trends linked to organizations costs and economic impact in I4.0, presented in literature and identified by the authors, are listed in Table 8.

Table 8. Trends liked to organizations costs and economic impact in I4.0

\begin{tabular}{|c|c|c|}
\hline Trend & References & Discussion \\
\hline $\begin{array}{l}\text { Additive \& Hybrid } \\
\text { manufacturing }\end{array}$ & {$[47,74,75,76]$} & $\begin{array}{l}\text { - batch size one is achieved very fast and cheap } \\
\text { and they permit personalized products }\end{array}$ \\
\hline Cloud manufacturing & $\begin{array}{l}{[21,33,37} \\
38,39,76]\end{array}$ & $\begin{array}{l}\text { - turn the free manufacturing resources into } \\
\text { cheap services and allow an easy way to order } \\
\text { and to produce parts }\end{array}$ \\
\hline $\begin{array}{l}\text { Virtual procedures, } \\
\text { instructions and maps } \\
\text { for maintenance }\end{array}$ & {$[45,46]$} & $\begin{array}{l}\text { - can reduce costs by avoiding the presence of } \\
\text { external technicians }\end{array}$ \\
\hline $\begin{array}{l}\text { Real-time process } \\
\text { optimization }\end{array}$ & {$[1,51]$} & $\begin{array}{l}\text { - self-optimizing of cutting parameters can } \\
\text { reduce cycle time, reduce energy consumption } \\
\text { and increase tool life. }\end{array}$ \\
\hline $\begin{array}{l}\text { More products } \\
\text { recycled and faster }\end{array}$ & {$[1,5,61]$} & $\begin{array}{l}\text { - once with the transition to smart products, } \\
\text { the smart factories will be able to recycle more } \\
\text { and faster; these issues will lead to high cost } \\
\text { savings and conservation of natural resources }\end{array}$ \\
\hline Smart products & {$[1,3,75]$} & $\begin{array}{l}\text { - the smart products will know their own } \\
\text { history, from manufacture to recycle, and the } \\
\text { information stored by these products in the } \\
\text { entire lifecycle will help to identify certain } \\
\text { components for reuse }\end{array}$ \\
\hline $\begin{array}{l}\text { Own energy sources } \\
\text { (electricity) }\end{array}$ & Authors hypothesis & $\begin{array}{l}\text { - own energy source means low energy cost, } \\
\text { revenues by selling extra-energy and reducing } \\
\text { the dependence on external suppliers }\end{array}$ \\
\hline
\end{tabular}

Additive manufacturing (AM) is a vital component of I4.0, a key technology for manufacture customized products $[74,75,76]$. Using AM in FoF, batch size one can be achieved very cheap. Today, AM represents a good opportunity and a low-cost solution to repair/reshape parts or tools e.g. dies, moulds [74, 75] or made special turning knifes. Even if the constraints regarding surface quality, tolerances, hardness and mechanical properties hinder widespread use, AM has not yet shown its true value and the outlook looks favourable. Current researches in AM will bring soon changes in traditional manufacturing.

MT4.0 which includes self-optimizing, sensing technologies and intelligent maintenance radically change the way to manufacture products. The maintenance cost will decrease by using remote maintenance right on time, and the energy cost and tools cost will decrease by self-optimizing of cutting parameters without increasing cycle time. The machine-tool will know when to decrease an increase the cutting parameters (feed rate \& cutting speed), and coolant volume and pressure, to gain the best use of resources (maximum tool life and minimum energy consumption). Already some cutting tools manufacturers e.g. Walter Tools, Sandvik Coromant developed solutions for real-time optimizing of cutting parameters and may be integrated in production systems such as SaaS.

The renewable energies have become the main energy source in many countries and play an important role in global economy. The cost of equipment e.g. wind mill and solar panel have fallen in recent years while the reliability has increased and thus, in manufacturing FoF the trend may be in 
designing and creating of own sources of renewable energies, in the context of smart grid. The impact will be both, decrease of energy cost and increase of revenues by selling the extra-energy. Regarding the human resource, the automation of processes means lower operators, thus is expected a decrease of labour cost along with some increase of cost for training, if isn't performed in-house.

Even if large cost savings are expected, there are many concerns about how much will cost the digitalization. The introduction of newer ICT, development of a new IT infrastructure, the equipment and machine-tools upgrade and human resource development may require substantial investment [5]. FoF also will change the way of how and how much companies are recycling. Manufacturers which will produce smart products will be able to recycle more and faster $[1,5,61]$ and this means that new business model focused on recycling and sustainable development, with high impact in costs saving and conservation of natural resources shall to be established between suppliers and customers. As well, the information stored by smart products on their entire lifecycle, their own history from manufacturing to recycling, will be used to identify certain components for reuse $[1,3]$. The challenges linked to organizations costs and economic impact in I4.0, presented in literature and identified by the authors, are listed in Table 9.

Table 9. The challenges linked to organizations costs and economic impact in I4.0

\begin{tabular}{lc}
\hline \multicolumn{1}{c}{ Challenge } & References \\
\hline Funding and how much will cost & {$[3,5,6]$} \\
\hline Transition of small and medium enterprise to & {$[2,5]$} \\
I4.0 & {$[1,16,17]$} \\
\hline Development of smart products & {$[74]$} \\
\hline High quality additive manufacturing & Authors hypothesis \\
\hline $\begin{array}{l}\text { Crossing from classical manufacturing to } \\
\text { unconventional and additive }\end{array}$ & \\
\hline
\end{tabular}

\section{Conclusions}

Industry 4.0 is expected to change the way of how the products are made. ICT are coming to support the factories transition from traditional manufacturing to smart manufacturing integrating devices, equipment, machines and people to create Factory of the Future. New business models and strategies will emerge and more environmental friendly products and processes will arise, focused towards on value creation and sustainable development. The manufacturing processes will integrate the newest IC technologies to create smart manufacturing and sustainable factories, thus new trends and challenges for global environment are arising.

This paper brings a better view and a better understand of I4.0, reveal the trends and the challenges of manufacturing management and give an outlook for further researches. It can be strengthened the idea that I4.0 is a complex process that require a lot of specialists from different fields, time and funds for it implementations and for integration of all the functions.

The mapped benefits and ideas of I4.0 has to be shifted from vision to reality [2] i.e. it is necessary not only to develop strategies and to have ideas about future but also must to accelerate the implementation process of Industry 4.0, to have results and to quantify real benefits. The concerns of digitalization are focused mainly on SMeS due to lack of resources $[2,5]$ and therefore for the successful integration of all stakeholders from supply chains are necessary large investments supported not only by corporations, but also by governments [23]. However, probably, the most valuable resource for the future success of Industry 4.0 is the human resource and should be treated with priority.

\section{Acknowledgment}

The authors would like to thank the Interdisciplinary Doctoral School, Transilvania University of Brasov, Romania, and the Research and Development Unit for Mechanical and Industrial Engineering (UNIDEMI), Universidade Nova de Lisboa, Portugal, for their support in this research. The vectors/icons from figures was provided by Freepik from www.flaticon.com. 


\section{References}

1. Kagermann H., Wahlster W., Helbig J. (2013): Recommendations for implementing the strategic initiative INDUSTRIE 4.0. Final Rep Ind 40 WG 82, ISSN: 2405-8963, April, p. 1-82, DOI: 10.13140/RG.2.1.1205.8966, https://www.din.de/blob/76902/e8cac883f42bf28536e7e8165993f1fd/recommendations-forimplementing-industry-4-0-data.pdf

2. Sommer L. (2015): Industrial revolution - industry 4.0-Are German manufacturing SMEs the first victims of this revolution? Journal of Industrial Engineering and Management, eISSN: 2013-0953, Vol. 8, Is. 5, p. 1512-1532, http://dx.doi.org/10.3926/jiem.1470

3. Stock T., Seliger, G. (2016): Opportunities of Sustainable Manufacturing in Industry 4.0. Procedia CIRP, ISSN: $2212-$ 8271, Vol. 40, p. 536-541, https://doi.org/10.1016/j.procir.2016.01.129

4. Roblek V., Meško M., Krapež, A. (2016): A Complex View of Industry 4.0. SAGE Open, ISSN: 2158-2440, Vol. 6, Is. 2, p. 1-11, https://doi.org/10.1177/2158244016653987

5. Schröder C. (2015): The Challenges of Industry 4.0 for Small and Medium-Sized Enterprises. Friedrich Ebert Found, ISBN: 94-3-95861-543-4, November, p. 1-28, http://library.fes.de/pdf-files/wiso/12683.pdf

6. Neugebauer, R., Hippmann S., Leis M., Landherr M. (2016): Industrie 4.0 - From the Perspective of Applied Research. Procedia CIRP, ISSN: 2212-8271, Vol. 57, p. 2-7, https://doi.org/10.1016/j.procir.2016.11.002

7. https://www.sentryo.net/the-4-industrial-revolutions/. Accessed: 2018-10-26

8. Kolberg D., Zühlke D. (2015): Lean Automation Enabled by Industry 4.0 Technologies. IFAC-PapersOnLine, ISSN: 2405-8963, Vol. 48, Is. 3, p. 1870-1875, https://doi.org/10.1016/j.ifacol.2015.06.359

9. http://www.cibersur.pt/index.php/industria-4-0. Accessed: 2017-10-20

10. Lu Y. (2017): Industry 4.0: A Survey on Technologies, Applications and Open Research Issues. Journal of Industrial Information Integration, ISSN: 2452-414X, Vol. 6, p. 1-10, https://doi.org/10.1016/j.jii.2017.04.005

11. Zaslavsky A., Jayaraman P.P. (2015): Discovery in the Internet of Things. Ubiquity, ISSN: 1530-2180, October, p. 1-10, DOI: $10.1145 / 2822529$

12. Carreiro P. (2015): Industry 4.0: an industrial evolution, rather than a revolution. Available at: http://www.techradar.com/news/world-of-tech/industry-4-0-an-industrial-evolution-rather-than-arevolution-1286048. Accessed: 2017-10-22

13. Denkena B., Mörke T., Krüger M., Schmidt J., Boujnah H., Meyer J., Gottwald P., Spitschan B., Winkens M. (2014): Development and First Applications of Gentelligent Components over Their Lifecycle. CIRP Journal of Manufacturing Science and Technology, ISSN: 1755-5817, Vol. 7, Is. 2, p. 139-150, https://doi.org/10.1016/i.cirpj.2013.12.006

14. Pinzone M., Fantini P., Perini S., Garavaglia S., Taisch M., Miragliotta G. (2017): Jobs and Skills in Industry 4.0 : An Exploratory Research. APMS, IFIP WG 5.7 International Conference, ISBN: 978-3-319-66923-6, p. 282-288, September 3-7, Hamburg, Germany, https://doi.org/10.1007/978-3-319-66923-6_33

15. Prinz C., Morlock F., Freith S., Kreggenfeld N., Kreimeier D., Kuhlenkötter B. (2016): Learning Factory Modules for Smart Factories in Industrie 4.0. Procedia CIRP, ISSN: 2212-8271, Vol. 54, p. 113-118, https://doi.org/10.1016/j.procir.2016.05.105

16. Zhou K., Liu T., Zhou L. (2015): Industry 4.0: Towards Future Industrial Opportunities and Challenges. IEEE, $12^{\text {th }}$ International Conference on Fuzzy Systems and Knowledge Discovery (FSKD), ISBN: 978-1-4673-7682-2, p. 2147-2152, 15-17 Aug. 2015, Zhangjiajie, China, DOI: 10.1109/FSKD.2015.7382284

17. Zuehlke D. (2010): SmartFactory-Towards a Factory-of-Things. Annual Reviews in Control, ISSN: 1367-5788, Vol. 34, Is. 1, p. 129-138, https://doi.org/10.1016/j.arcontrol.2010.02.008

18. Wagner T., Herrmann C., Thiede S. (2017): Industry 4.0 Impacts on Lean Production Systems. Procedia CIRP, ISSN: 2212-8271, Vol. 63, p. 125-131, https://doi.org/10.1016/j.procir.2017.02.041

19. Atzori L., Iera A., Morabito, G. (2010): The Internet of Things: A survey. Computer Networks, ISSN: 1389-1286, Vol. 54, Is. 15, p. 2787-2805, https://doi.org/10.1016/i.comnet.2010.05.010

20. Qin J., Liu Y., Grosvenor, R. (2016): A Categorical Framework of Manufacturing for Industry 4.0 and Beyond. Procedia CIRP, ISSN: 2212-8271, Vol. 52, p. 173-178, https://doi.org/10.1016/j.procir.2016.08.005

21. Thames L., Schaefer D. (2016): Software-Defined Cloud Manufacturing for Industry 4.0. Procedia CIRP, ISSN: 2212-8271, Vol. 52, p. 12-17, https://doi.org/10.1016/j.procir.2016.07.041

22. Khan M., Wu X., Xu X., Dou W. (2017): Big Data Challenges and Opportunities in the Hype of Industry 4.0. IEEE, 2017 IEEE International Conference on Communications (ICC), ISBN: 978-1-4673-8999-0, 21-25 May, Paris, France, DOI: 10.1109/ICC.2017.7996801, https://ieeexplore.ieee.org/stamp/stamp.jsp?arnumber=7996801

23. Klingenberg C.O., Antunes J.A. (2017): Industry 4.0 : What Makes It a Revolution? EurOMA, Edinburgh, Scotland, 1-5 July 2017, https://www.researchgate.net/publication/319127784

24. Pîrvu B.C., Zamfirescu, C.B. (2017): Smart Factory in the Context of 4th Industrial Revolution: Challenges and Opportunities for Romania. IOP Conf. Ser. Mater. Sci. Eng., ISSN: 1757-899X, Vol. 227, Is. 1, p. 1-10, DOI: 
10.1088/1757-899X/227/1/012094

25. Thiede S., Juraschek M., Herrmann C. (2016): Implementing Cyber-Physical Production Systems in Learning Factories. Procedia CIRP, ISSN: 2212-8271, Vol. 54, p. 7-12, https://doi.org/10.1016/j.procir.2016.04.098

26. Duroc Y., Kaddour D. (2012): RFID Potential Impacts and Future Evolution for Green Projects. Energy Procedia, ISSN: 1876-6102, Vol. 18, p. 91-98, https://doi.org/10.1016/i.egypro.2012.05.021

27. Weis S.A. (2010): RFID (Radio Frequency Identification): Principles and Applications. Available at: https://www.rfid-off.com/uploads/4/5/1/2/45128343/rfid-article mit usa.pdf

28. Duroc Y., Tedjini S. (2018): RFID: A key technology for Humanity. Comptes Rendus Physique, ISSN: 1631-0705, Vol. 19(1-2), p. 64-71, https://doi.org/10.1016/i.crhy.2018.01.003

29. Yan B., Huang G. (2009): Supply Chain Information Transmission Based on RFID and Internet of Things. ISECS International Colloquium on Computing, Communication, Control, and Management, ISBN: 978-1-4244-42478, p. 166-169, DOI: 10.1109/CCCM.2009.5267755, https://ieeexplore.ieee.org/document/5267755

30. Zhong R.Y., Newman S.T., Huang G.Q., Lan S. (2016): Big Data for supply chain management in the service and manufacturing sectors: Challenges, opportunities, and future perspectives. Computers \& Industrial Engineering, ISSN: 0360-8352, Vol. 101, p. 572-601, https://doi.org/10.1016/i.cie.2016.07.013

31. Witkowski K. (2017): Internet of Things, Big Data, Industry 4.0 - Innovative Solutions in Logistics and Supply Chains Management. Procedia Engineering, ISSN: 1877-7058, Vol. 182, p. 763-769, https://doi.org/10.1016/j.proeng.2017.03.197

32. Chen B., Wan J., Shu L., Li P., Mukherjee M., Yin B. (2017): Smart Factory of Industry 4.0: Key Technologies, Application Case, and Challenges. IEEE Access, ISSN: 2169-3536, Vol. 6, p. 6505-6519, DOI: 10.1109/ACCESS.2017.2783682

33. Tao F., Zhang L., Venkatesh V.C., Luo Y., Cheng Y. (2011): Cloud manufacturing: a computing and service-oriented manufacturing model. Proceedings of the Institution of Mechanical Engineers, Part B: Journal of Engineering Manufacture, ISSN: 0954-4054, Vol. 225, No. 10, p. 1969-1976, https://doi.org/10.1177/0954405411405575

34. https://www.ibm.com/cloud/learn/what-is-cloud-computing. Accessed: 2018-06-16

35. https://www.clausweb.ro/blog/ce-este-cloud-computing/. Accessed: 2018-06-16

36. https://despretot.info/cloud-computing-definitie-referat/. Accessed: 2018-06-16

37. Talhi A., Huet J.C., Fortineau V., Lamouri S. (2015): Towards a Cloud Manufacturing Systems Modeling Methodology. IFAC-PapersOnLine, Vol. 28, Is. 3, p. 288-293, https://doi.org/10.1016/j.ifacol.2015.06.096

38. Caggiano A., Segreto T., Teti R. (2016): Cloud Manufacturing Framework for Smart Monitoring of Machining. Procedia CIRP, ISSN: 2212-8271, Vol. 55, p. 248-253, https://doi.org/10.1016/j.procir.2016.08.049

39. Zhou Z., Fuh J., Xie S., Jiang Z. (2015): Digital Manufacturing and Cloud Manufacturing. Editorial. Advances in Mechanical Engineering, ISSN: 1687-8132, p. 2-3, https://doi.org/10.1155/2013/560691

40. Varghese A., Tandur D. (2014): Wireless requirements and challenges in Industry 4.0. International Conference on Contemporary Computing and Informatics (IC3I), ISBN: 978-1-4799-6629-5, p. 634-638, Mysuru, India, 27-29 Nov. 2014, DOI: 10.1109/IC3I.2014.7019732

41. Li S., Xu L.D., Zhao S. (2018): 5 G Internet of Things: A survey. Journal of Industrial Information Integration, ISSN: 2452-414X, Vol. 10, p. 1-9, https://doi.org/10.1016/i.jii.2018.01.005

42. Uhlmann E., Laghmouchi A., Geisert C., Hohwieler E. (2017): Decentralized Data Analytics for Maintenance in Industrie 4.0. Procedia Manufacturing, ISSN: 2351-9789, Vol. 11, p. 1120-1126, https://doi.org/10.1016/j.promfg.2017.07.233

43. Hecklau F., Galeitzke M., Flachs S., Kohl H. (2016): Holistic Approach for Human Resource Management in Industry 4.0. Procedia CIRP, ISSN: 2212-8271, Vol. 54, p. 1-6, https://doi.org/10.1016/j.procir.2016.05.102

44. Hill D.C., Seabrook, K.A. (2013): Safety \& Sustainability. Understanding the Business Value. Available at: https://pdfs.semanticscholar.org/6670/faccc6d7217153527e29dee91139248c5461.pdf. Accessed: 201810-25

45. Schmitt M., Meixner G., Gorecky D., Seissler M., Loskyll M. (2013): Mobile interaction technologies in the factory of the future. IFAC Proceedings Volumes, ISSN: 1474-6670, Vol. 46, No. 15, p. 536-542, https://doi.org/10.3182/20130811-5-US-2037.00001

46. Gorecky D., Schmitt M., Loskyll M., Zühlke D. (2014): Human-machine-interaction in the industry 4.0 era. $12^{\text {th }}$ IEEE International Conference on Industrial Informatics (INDIN), ISBN: 978-1-4799-4905-2, p. 289-294, Porto Alegre RS, Brazil, 27-30 Jul., DOI: 10.1109/INDIN.2014.6945523

47. Bortolini M., Ferrari E., Gamberi M., Pilati F., Faccio M. (2017): Assembly system design in the Industry 4.0 era: a general framework. IFAC-PapersOnLine, ISSN: 2405-8963, Vol. 50, No. 1, p. 5700-5705, https://doi.org/10.1016/j.ifacol.2017.08.1121

48. Khalid A., Kirisci P., Ghrairi Z., Thoben K.-D., Pannek J. (2007): Towards Implementing Safety and Security

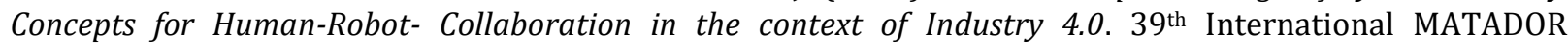
Conference, Manchester, U.K., https://www.researchgate.net/publication/318340673 
RECENT, Vol. 19, no. 2(55), November, 2018

49. Gašová M., Gašo M., Štefánik A. (2017): Advanced Industrial Tools of Ergonomics Based on Industry 4.0 Concept. Procedia Engineering, ISSN: 1877-7058, Vol. 192, p. 219-224, https://doi.org/10.1016/i.proeng.2017.06.038

50. Lukač D. (2015): The fourth ICT-based industrial revolution "industry 4.0" - HMI and the case of CAE/CAD innovation with EPLAN P8. 23rd Telecommunications Forum Telfor (TELFOR), ISBN: 978-1-5090-0055-5, p. 835-838, Belgrade, Serbia, https://ieeexplore.ieee.org/stamp/stamp.jsp?tp=\&arnumber=7377595

51. Liu C., Xu X. (2017): Cyber-physical Machine Tool - The Era of Machine Tool 4.0. Procedia CIRP, ISSN: 2212-8271, Vol. 63, p. 70-75, https://doi.org/10.1016/j.procir.2017.03.078

52. Longo F., Nicoletti L., Padovano A. (2017): Smart operators in industry 4.0: A human-centered approach to enhance operators' capabilities and competencies within the new smart factory context. Computers \& Industrial Engineering, ISSN: 0360-8352, Vol. 113, p. 144-159, https://doi.org/10.1016/i.cie.2017.09.016

53. Benešová A., Tupa J. (2017): Requirements for Education and Qualification of People in Industry 4.0. Procedia Manufacturing, ISSN: 2351-9789, Vol. 11, p. 2195-2202, https://doi.org/10.1016/i.promfg.2017.07.366

54. Baena F., Guarin A., Mora J., Sauza J., Retat S. (2017): Learning Factory: The Path to Industry 4.0. Procedia Manufacturing, ISSN: 2351-9789, Vol. 9, p. 73-80, https://doi.org/10.1016/i.promfg.2017.04.022

55. Tupa J., Simota J., Steiner F. (2017): Aspects of Risk Management Implementation for Industry 4.0. Procedia Manufacturing, ISSN: 2351-9789, Vol. 11, p. 1223-1230, https://doi.org/10.1016/i.promfg.2017.07.248

56. Kans M., Ingwald A. (2016): Business Model Development Towards Service Management 4.0. Procedia CIRP, ISSN: 2212-8271, Vol. 47, p. 489-494, https://doi.org/10.1016/i.procir.2016.03.228

57. Oliff H., Liu Y. (2017): Towards Industry 4.0 Utilizing Data-Mining Techniques: A Case Study on Quality Improvement. Procedia CIRP, ISSN: 2212-8271, Vol. 63, p. 167-172, https://doi.org/10.1016/i.procir.2017.03.311

58. Chiu Y.-C., Cheng F.-T., Huang H.-C. (2017): Developing a factory-wide intelligent predictive maintenance system based on Industry 4.0. Journal of the Chinese Institute of Engineers, ISSN: 0253-3839, Vol. 40, Is. 7, p. 562-571, https://doi.org/10.1080/02533839.2017.1362357

59. Upasani K., Bakshi M., Pandhare V., Lad B.K. (2017): Distributed maintenance planning in manufacturing industries. Computers \& Industrial Engineering, ISSN: 0360-8352, Vol. 108, p. 1-14, https://doi.org/10.1016/j.cie.2017.03.027

60. Masoni R., Ferrise F., Bordegoni M., Gattullo M., Uva A.E., Fiorentino M., Carrabba E., Di Donato M. (2017): Supporting Remote Maintenance in Industry 4.0 through Augmented Reality. Procedia Manufacturing, ISSN: 2351-9789, Vol. 11, p. 1296-1302, https://doi.org/10.1016/j.promfg.2017.07.257

61. Kayikci Y. (2018): Sustainability impact of digitization in logistics. Procedia Manufacturing, ISSN: 2351-9789, Vol. 21, p. 782-789, https://doi.org/10.1016/i.promfg.2018.02.184

62. Schrauf S., Berttram P. (2016): Industry 4.0: How digitization makes the supply chain more efficient, agile, and customer-focused. Available at: https://www.strategyand.pwc.com/reports/digitization-more-efficient. Accessed: 2017-10-08

63. Hermann M., Pentek T., Otto B. (2016): Design Principles for Industrie 4.0 Scenarios. 49th Hawaii International Conference on System Sciences (HICSS), ISBN: 978-0-7695-5670-3, p. 3928-3937, Koloa, HI, USA, 5-8 Jan., DOI: $10.1109 /$ HICSS.2016.488

64. Wang S., Wan J., Li D., Zhang C. (2016): Implementing Smart Factory of Industrie 4.0: An Outlook. International Journal of Distributed Sensor Networks, Vol. 12, No. 1, p. 1-10, https://doi.org/10.1155/2016/3159805

65. Oleśków-Szłapka J., Lubiński P. (2016): New Technology Trends and Solutions in Logistics and Their Impact on Processes. 3rd International Conference on Social Science (ICSS), ISBN: 978-1-60595-410-3, p. 408-413, Shangai, China, 9-11 Dec., DOI: 10.12783/dtssehs/icss2016/8989

66. Hofmann E., Rüsch M. (2017): Industry 4.0 and the current status as well as future prospects on logistics. Computers in Industry, ISSN: 0166-3615, Vol. 89, p. 23-34, https://doi.org/10.1016/j.compind.2017.04.002

67. Madleňák R., Madleňáková L., Kolarovszká Z. (2016): System of Management and Traceability of Logistic Items through New Technologies. Procedia - Social and Behavioral Sciences, ISSN: 1877-0428, Vol. 230, September, p. 128-135, https://doi.org/10.1016/i.sbspro.2016.09.016

68. Yan B., Huang G. (2009): Supply chain information transmission based on RFID and internet of things. ISECS International Colloquium on Computing, Communication, Control, and Management, ISBN: 978-1-4244-42478, p. 166-169, Sanya, China, https://ieeexplore.ieee.org/stamp/stamp.jsp?tp=\&arnumber $=5267755$

69. Montreuil B., Meller R.D., Ballot E. (2010): Towards a Physical Internet: the impact on logistics facilities and material handling systems design and innovation. https://pdfs.semanticscholar.org/a907/08526f1c787 bdafbcebf8492583b7ef668d4.pdf

70. Maslarić M., Nikoličić S., Mirčetić D. (2016): Logistics Response to the Industry 4.0: The Physical Internet. Open Engineering, ISSN: 2391-5439, Vol. 6, No. 1, p. 511-517, https://www.degruyter.com/downloadpdf/i/ eng.2016.6.issue-1/eng-2016-0073/eng-2016-0073.pdf

71. Buda A.T. (2015): The relationship between Industrial Engineering and Entrepreneurship in market economy conditions, PhD Thesis, Transilvania University of Brasov, Romania (in Romanian) 
72. Trstenjak M., Cosic P. (2017): Process Planning in Industry 4.0 Environment. Procedia Manufacturing, ISSN: 2351-9789, Vol. 11, p. 1744-1750, https://doi.org/10.1016/i.promfg.2017.07.303

73. Müller J.M., Erdel M., Voigt K.-I. (2017): Industry 4.0 - Perspectives and challenges for project logistics. EurOMA Conference, Edinburgh, Scotland, https://www.researchgate.net/publication/318226682 Industry 40Perspectives and challenges for project logistics

74. Dilberoglu U.M., Gharehpapagh B., Yaman U., Dolen M. (2017): The Role of Additive Manufacturing in the Era of Industry 4.0. Procedia Manufacturing, ISSN: 2351-9789, Vol. 11, p. 545-554, https://doi.org/ 10.1016/i.promfg.2017.07.148

75. Santos K., Loures E., Piechnicki F., Canciglieri O. (2017): Opportunities Assessment of Product Development Process in Industry 4.0. Procedia Manufacturing, ISSN: 2351-9789, Vol. 11, p. 1358-1365, https://doi.org/10.1016/i.promfg.2017.07.265

76. Rudolph J.P., Emmelmann C.A. (2017): Cloud-based Platform for Automated Order Processing in Additive Manufacturing. Procedia CIRP, ISSN: 2212-8271, Vol. 63, p. 412-417, https://doi.org/10.1016/.procir.2017.03.087

Received: 30 October 2018; Accepted: 07 November 2018 